\title{
Spatial patterns of maternal investment in Strongylocentrotus franciscanus along a marine-terrestrial gradient
}

\author{
Michael S. Berger ${ }^{1,3, *}$, Dennis E. Jelinski ${ }^{2}$ \\ ${ }^{1}$ Bamfield Marine Sciences Centre, Bamfield, British Columbia, V0R 1B0, Canada \\ ${ }^{2}$ Laboratory for Ecosystem and Landscape Ecology, Department of Geography, University of Victoria, Victoria, \\ British Columbia V8W 3P5, Canada
}

${ }^{3}$ Present address: Science Programs, Washington State University, Vancouver, 14204 NE Salmon Creek Avenue, Vancouver, Washington 98686-9064, USA

\begin{abstract}
In near-shore marine ecosystems, organisms inhabit an interface between marine and terrestrial environments where both systems interact in complex ways. These interactions may occur along gradients in biophysical conditions that vary over spatial and temporal scales. These environmental conditions are known to drive many biological processes with resulting influence on a given species life history. In the present study we examined spatial variation in indices of reproductive fitness, namely fecundity, egg volume, and egg biochemistry in the red sea urchin Strongylocentrotus franciscanus along a spatial gradient of decreasing wave energy and increasing terrestrial influence in Barkley Sound, British Columbia, Canada. Stable carbon $\left(\delta^{13} C\right)$ isotopic analysis was used as a bioindicator of (1) the influence of terrestrially derived carbon in egg production and (2) the concomitant effects of assimilation of terrestrial carbon on egg quality. Stable nitrogen $\left(\delta^{15} \mathrm{~N}\right)$ isotopic analysis was used to assess trophic status among and within locations and relate this back to the strength of the gradients. We found that urchins in the lowest energy wave environment released the most eggs compared to all other locations. Egg volume was similar across all sites in the present study; however, within each site, mean egg volume varied among female urchins. Egg biochemistry (e.g. protein, carbohydrate and lipid levels), a proxy for egg quality, was the same at all sites, although analysis of percent carbon, a proxy for lipids, suggested a trend in increasing levels as distance from high wave energy environments increased. No obvious spatial pattern in $\delta^{13} \mathrm{C}$ was observed, suggesting that input of terrestrial organic material is well diluted in Barkley Sound. With respect to $\delta^{15} \mathrm{~N}$, we found little variation in trophic level at which foraging takes place. In contrast there were different $\delta^{13} \mathrm{C}$ and $\delta^{15} \mathrm{~N}$ levels when comparing egg to tube foot tissue, suggesting that temporally $S$. franciscanus was feeding on different food sources or that for these tissue types urchins differentially assimilate carbon and nitrogen isotopes.
\end{abstract}

KEY WORDS: Urchin · Stable isotopes · Barkley Sound · Terrestrial-marine interactions · Egg biochemistry

Resale or republication not permitted without written consent of the publisher

\section{INTRODUCTION}

In near-shore marine ecosystems, organisms inhabit an interface between marine and terrestrial environments where both systems interact in complex ways. For example, land-based runoff has long been thought to enhance demersal fishery production in various coastal areas where fish abundance follows river discharge variations (Cushing 1995, Lloret et al. 2001). This is believed to reflect a combination of terrestrial land-based nutrient runoff that affects phytoplankton production (see Darnaude 2005) and efficient exploi- 
tation of river-borne particulate organic matter (POM) by some benthic organisms, which in turn contribute to the demersal fish web (Darnaude et al. 2004). The influences of terrestrial ecosystems on the near-shore are most pronounced during river floods (Darnaude 2005). Further, the interaction is enhanced in the absence of large estuaries that buffer terrestrial and/or anthropogenic input into the ocean.

The nature of this terrestrial-marine interaction is often expressed in the marine landscape as a gradient of conditions for variables including salinity, chlorophyll, light, terrestrially derived dissolved organic material (DOM) or particulate organic material (POM), and temperature (Longhurst 1998). These biogeochemical gradients provide interesting opportunities to examine their influence on life-history traits in marine benthic invertebrates (McEdward \& Carson 1987, Berger et al. 2006). This is particularly important, as there are comparatively few studies of variability in maternal nutrition for benthic invertebrates along unidirectional gradients of environmental conditions. Maternal nutrition and resultant egg properties (e.g. number of eggs, egg size, and egg quality) are known to be closely tied to habitat-mediated differences in food availability and quality (George et al. 1990, Bertram \& Strathmann 1998). Indeed, maternal nutritional stress has been found to produce eggs with lower organic content, protein concentrations, and lipid reserves (Bayne et al. 1978, George et al. 1990). Habitat differences that affect urchin nutrition include variation in macroalgal abundance and biochemical composition, which varies along a gradient of wave exposure (Harrold et al. 1988, Diez et al. 2003).

With an increase in storm events on the west coast of North America potentially due to global climate change (Graham \& Diaz 2001, Bromirski et al. 2003), there may be an attendant increase in precipitation. Elevated precipitation over coastal terrestrial ecosystems will result in increased levels of terrestrial organic material flowing into nearby marine systems. Freshwater often enters the ocean environment through an estuary, whence it forms a plume (gradient) and becomes a local source of momentum and buoyancy. These waters typically act as an exporter of organic material into marine systems (Day et al. 1989). Therefore, a greater influx of terrestrial organic material into the marine environment occurs along a wave exposure gradient as distance from the open ocean increases. In the context of global climate change, it is necessary to better understand the role of terrestrial-marine interactions given the potential for change to coastal climatology.

The objective of the present study was to investigate whether a gradient of wave energy and land-based carbon might affect reproductive dynamics in Strongylocentrotus franciscanus (A. Agassiz, 1863). Our study area is a large embayment, Barkley Sound, British Columbia, Canada. A hypermaritime climate in the region results in large freshwater outflows from watersheds in the Sound, creating a strong salinity gradient in the channel used in the present study. In addition, heavy winter rains create a strong freshwater lens. The nature of the embayment is also structured such that there is a wave exposure gradient along an east-west axis (Salomon et al. 2006). Thus our study area included a strong terrestrial gradient that weakens with increasing exposure to the open ocean with its attendant gradient of wave energy.

The use of stable carbon isotope analysis can be a valuable tool to infer whether ingested food has a marine or terrestrial origin (Gannes et al. 1997). Lower carbon isotope ratios (more negative) indicate a terrestrial origin and higher values (more positive) a marine origin. Stable nitrogen isotope ratios are frequently used to determine trophic level (McCutchan et al. 2003). Consumption of higher trophic level food sources will result in higher (more positive) isotope ratios. An increase of 3 to $4 \%$ in nitrogen isotope ratio indicates a shift in trophic level feeding (McCutchan et al. 2003).

We coupled isotope analysis with measurements of life-history traits in urchins. Specifically, we addressed the following questions: (1) Does the number of eggs released vary along a horizontal wave exposure gradient? (2) Does egg volume vary along this gradient? (3) Does egg biochemistry (e.g. protein, carbohydrate, and lipid levels) vary along this gradient? (4) Do stable carbon and nitrogen isotopic signatures in reproductive (i.e. eggs) and somatic tissue (i.e. tube feet) vary along this gradient? A corollary to this last question is: What effect, if any, does carbon source (e.g. marine or terrestrial) have on egg quality?

\section{MATERIALS AND METHODS}

Study area. Barkley Sound is a large embayment $\left(>550 \mathrm{~km}^{2}\right)$ on the west coast of Vancouver Island. It is divided into 3 channels; our study area was located in Trevor Channel, which is narrow and deep $(150 \mathrm{~m})$ and leads to the $350 \mathrm{~m}$ deep waters of Alberni Inlet. This channel is most heavily influenced by freshwater outflow from the $45 \mathrm{~km}$ long Alberni inlet (Tully 1949, Taylor \& Haigh 1996), especially during the time an Aleutian Low dominates from late September through May, resulting in significant precipitation in coastal ecosystems. Thus, near-surface salinities show that freshest waters appear during winter, which coincides with rainfall maxima. For example, in the month of 
May, Romanuk \& Levings (2006) found surface salinities ranging from 4 to 33 (mean 25.8, SD 6.9). At the same time the winds are predominantly equatorward along the coast, resulting from the North Pacific high pressure system, which is favorable for upwelling. Intermediate waters exchange with the ocean in January through April; at other times of the year they stagnate and dissolved $\mathrm{O}_{2}$ levels drop to as low as $1 \mathrm{ml} \mathrm{l}^{-1}$. Tides are generally inphase over the Sound and tidal mixing is weak.

Collection and sample preparation. Strongylocentrotus franciscanus were collected between 25 May to 1 June 2005 using SCUBA at 6 sites along a $14 \mathrm{~km}$ transect running in a southwest to northeast direction in Barkley Sound, British Columbia, Canada $\left(48^{\circ} 50.04^{\prime} \mathrm{N}\right.$, $\left.125^{\circ} 08.21^{\prime} \mathrm{W}\right)$. Approximately 50 urchins were collected subtidally at $8 \mathrm{~m}$ depth on the southeast side of islands in the Deer Group, specifically Bordelais, Edward King, Diana, Wizard, Fleming and Tzartus (Fig. 1, Table 1). Urchins were abundant at all sites. Substrate was algal covered rocks at all sites except Fleming, which was sand interspersed with boulders. During the sampling period, adult urchins were separated according to collection site and maintained in a seawater table at ambient temperature. Due to the time consuming process of collecting urchins at multiple sites, collecting and aliquoting egg samples, and collecting tube feet, urchins were held without access to food for a maximum of $17 \mathrm{~d}$. Spawning was randomized by site to reduce bias. Short-term starvation is suggested to have a limited impact. For example, wet body mass of the urchin Diadema antillarum did not decrease over a 2 wk period of starvation (Levitan 1989). Additionally, Lares \& Pomory (1998) have suggested that urchin gonad material is metabolized during long-term periods of starvation exceeding $4 \mathrm{wk}$.

Spawning was induced by intracoelomically injecting $5 \mathrm{ml}$ of $0.55 \mathrm{M} \mathrm{KCl}$ through the oral disk; eggs were collected and washed in seawater. Total number of eggs per individual (i.e. fecundity) was estimated by determining the density of eggs in 6 replicate subsamples. To measure egg size, a sample of eggs was pipetted onto a glass slide and digitally photographed
Table 1. Study sites in Barkley Sound, British Columbia. Height of Verrucaria sp. refers to the mean $(n=3)$ upper distributional limit above mean lower low water (MLLW) $\pm 95 \%$ CI (see 'Wave exposure'). Lowercase letters indicate significant difference based on a Tukey post hoc analysis $(\mathrm{p}<0.05)$. See Fig. 1 for site locations

\begin{tabular}{|lcc|}
\hline Site & $\begin{array}{c}\text { Distance along } \\
\text { transect }(\mathrm{km})\end{array}$ & $\begin{array}{c}\text { Height of Verrucaria sp. } \\
\text { above MLLW }(\mathrm{m})\end{array}$ \\
\hline Bordelais & 0 & $11.8 \pm 0.28 \mathrm{a}$ \\
Edward King & 1.7 & $6.5 \pm 0.52 \mathrm{~b}$ \\
Diana & 3.1 & $5.1 \pm 0.33 \mathrm{C}$ \\
Wizard & 6.6 & $4.1 \pm 0.20 \mathrm{~d}$ \\
Fleming & 8.8 & $4.6 \pm 0.36 \mathrm{c}, \mathrm{d}$ \\
Tzartus & 13.6 & $4.5 \pm 0.57 \mathrm{c}, \mathrm{d}$ \\
\hline
\end{tabular}


through a compound microscope at $20 \times$ magnification. Maximum egg diameter of the first 200 eggs encountered was calculated digitally using ImageJ (version 1.33, NIH). Egg volume ( $V)$ was estimated as a sphere using $V=4 / 3 \pi \mathrm{r}^{3}$, where $\mathrm{r}$ is the radius. To quantify egg biochemistry and for stable isotope analysis, 30000 eggs were estimated volumetrically from a solution of eggs suspended in seawater. Aliquots of 30000 eggs were placed into replicate $1.7 \mathrm{ml}$ microcentrifuge tubes and gently centrifuged at $100 \times g$ for $1 \mathrm{~min}$. The remaining seawater was removed, and samples were frozen at $-80^{\circ} \mathrm{C}$ for later analysis.

Wave exposure. The intertidal lichen Verrucaria sp., which was observed at all study sites, was used as a biological indicator of wave energy. The upper distributional limit of intertidal lichens increases in areas of high wave energy and resulting wave splash (Ballantine 1961, Reimchen 1979). On islands adjacent to all collection sites, a sight level was used to measure the highest elevation above mean lower low water (MLLW) for Verrucaria sp.

Egg biochemistry. Protein levels were determined by homogenizing lyophilized aliquots of 30000 eggs in $350 \mu$ distilled water, centrifuging at $8000 \times g$ for $5 \mathrm{~min}$ at $4^{\circ} \mathrm{C}$ and removing the supernatant. Protein concentration was calculated spectrophotometrically at $595 \mathrm{~nm}$ using a Coomassie Blue assay (BioRad) based on a Bradford protein assay (Bradford 1976) with bovine serum albumin as a standard. Proteins were not extracted in trichloroacetic acid (TCA). A preliminary experiment indicated no difference in protein levels from egg samples with protein extracted in TCA compared to samples that did not have protein extracted.

Total lipids were extracted from lyophilized aliquots of 30000 eggs following the charring method of Bligh \& Dyer (1959) as modified by Holland \& Gabbott (1971). Briefly, lyophilized aliquots of 30000 eggs were extracted in water:methanol:chloroform $(2: 2: 1)$ for $2 \mathrm{~h}$. A total of $200 \mu \mathrm{l}$ distilled water and $200 \mu \mathrm{l}$ chloroform were then added for a final water:methanol:chloroform ratio (v:v:v) of $4: 2: 3$ and then centrifuged at $8000 \times g$ for $10 \mathrm{~min}$. The lower phase was removed and dried under nitrogen. Samples were re-dissolved in $350 \mu \mathrm{l}$ chloroform, and a $50 \mu \mathrm{l}$ subsample was dried under nitrogen followed by the addition of $500 \mu \mathrm{l}$ sulfuric acid. Samples were heated at $140^{\circ} \mathrm{C}$ for $15 \mathrm{~min}$, cooled, and diluted with $1.5 \mathrm{ml}$ distilled water. Lipid concentration was calculated spectrophotometrically at $375 \mathrm{~nm}$ using tripalmitin as a standard.

Carbohydrate levels were determined using a ferricyanide reduction reaction following the methods of Holland \& Gabbott (1971). Accordingly, lyophilized aliquots of 30000 eggs were homogenized in $500 \mu \mathrm{l}$ distilled water, protein was extracted in cold 5\% TCA and the supernatant removed. The supernatant was hydrolyzed in $1 \mathrm{M} \mathrm{HCl}$ at $95^{\circ} \mathrm{C}$ for $2 \mathrm{~h}$. Carbohydrate concentration was calculated spectrophotometrically at $420 \mathrm{~nm}$ using glucose as a standard.

Stable isotope analysis. Stable carbon and nitrogen isotope analyses were performed on Strongylocentrotus franciscanus eggs and somatic tissue (i.e. tube feet). Immediately following spawning, tube feet were removed and frozen at $-80^{\circ} \mathrm{C}$ for later analysis. All samples were dried at $60^{\circ} \mathrm{C}$ to constant mass and then ground with a mortar and pestle to a fine powder after which $1 \mathrm{mg}( \pm 0.1 \mathrm{mg})$ of each sample was encapsulated in tin. Isotopic ratios of carbon and nitrogen were measured using an ANCA G/S/L sample preparation module coupled to a Tracer/20 mass spectrometer (Europa Scientific) at the Department of Soil Sciences, University of Saskatchewan. Ratios of carbon and nitrogen isotopes are expressed as:

$$
\delta X(\% \text { o })=\left[\left(R_{\text {sample }} / R_{\text {reference }}\right)-1\right] \times 10^{3}
$$

where $\delta=$ the measure of heavy to light isotope in the sample, $X={ }^{13} \mathrm{C}$ or ${ }^{15} \mathrm{~N}$ and $R$ is the corresponding ratio of ${ }^{13} \mathrm{C}:{ }^{12} \mathrm{C}$ or ${ }^{15} \mathrm{~N}:{ }^{14} \mathrm{~N}$ (Peterson \& Fry 1987). We also measured percent carbon and nitrogen as proxies for lipid and protein levels, respectively (Holland 1978), for both eggs and tube feet tissue. International Standard references are Vienna Pee Dee Belemnite (VPDB) for carbon and atmospheric $\mathrm{N}_{2}$ for nitrogen.

Data analysis. Data were analyzed with Systat (version 9.0, SPSS) and STATISTICA (version 6.0, StatSoft). To test the effect of location on fecundity, protein levels, carbohydrate levels and lipid levels, we used a 1-way ANOVA followed by a Tukey post hoc test to explore differences between sites. To test the effect of location on egg volume, a nested ANOVA was performed with female urchin (random factor) nested within location (fixed factor). To test the effect of location and tissue type on carbon and nitrogen stable isotope ratios, we used a 2-way factorial ANOVA for each isotope independently.

\section{RESULTS}

Using Verrucaria sp. as a biological indicator of relative wave energy, decreased wave energy was observed along the transect from Bordelais to Wizard Island (ANOVA, $F_{5,12}=201, \mathrm{p}=0.00$; Table 1). No measurable difference was recorded for sites among the islands of Wizard, Fleming, or Tzartus.

Location as a variable had a significant effect on Strongylocentrotus franciscanus fecundity (ANOVA, $F_{5,51}=3.46, p=0.009$; Fig. 2). Fecundity at Tzartus was at least 3 times higher compared to Bordelais, Edward King, or Wizard (Tukey honestly significant difference test, HSD, df $=51, \mathrm{p}<0.05)$. However, fecundity at 


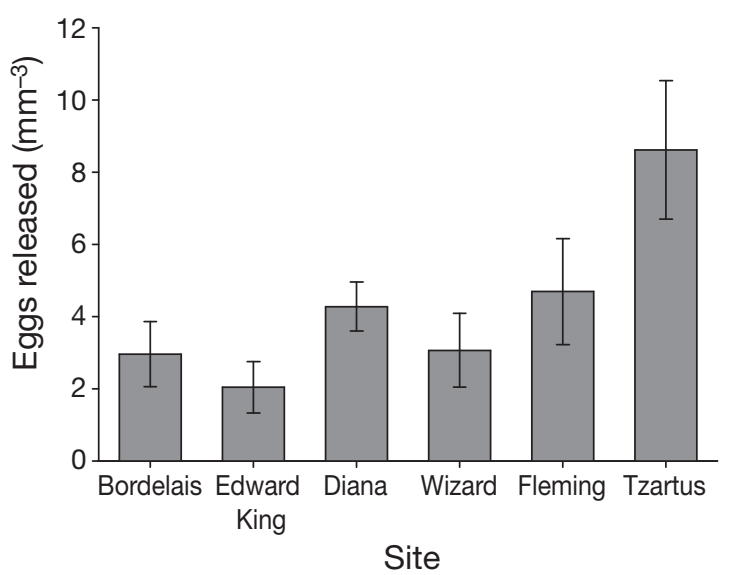

Fig. 2. Strongylocentrotus franciscanus. Fecundity of red sea urchins at 6 sites along a horizontal gradient in Barkley Sound. Number of eggs $S$. franciscanus released was normalized to test volume (test diameter ${ }^{3}$ ). Each bar represents the mean of 10 urchins, with the exception of 7 at Edward King. Error bars are $\pm 1 \mathrm{SE}$

Tzartus was not significantly higher $(p>0.05)$ compared to Diana and Fleming. Although the number of eggs released increased with adult test volume $(\mathrm{r}=$ $0.33, p=0.01$ ), adult test volume was not significantly correlated with individual egg volume $(r=0.07, p=$ $0.61)$.

Across locations egg volume did not significantly vary $\left(\right.$ ANOVA, $F_{5,49}=1.6, \mathrm{p}=0.27$ ). However, egg volume did significantly vary between females within a site (ANOVA, $F_{49,11106}=279, \mathrm{p}<0.001 ;$ Fig. 3 ).

Egg biochemistry, used as a proxy for egg quality, remained constant across all locations (Fig. 4). Protein levels (ANOVA, $F_{5,51}=2.12, \mathrm{p}=0.08$ ), carbohydrate levels (ANOVA, $F_{5,51}=1.93, \mathrm{p}=0.1$ ), and lipid levels (ANOVA, $F_{5,51}=2.28, \mathrm{p}=0.06$ ) did not significantly

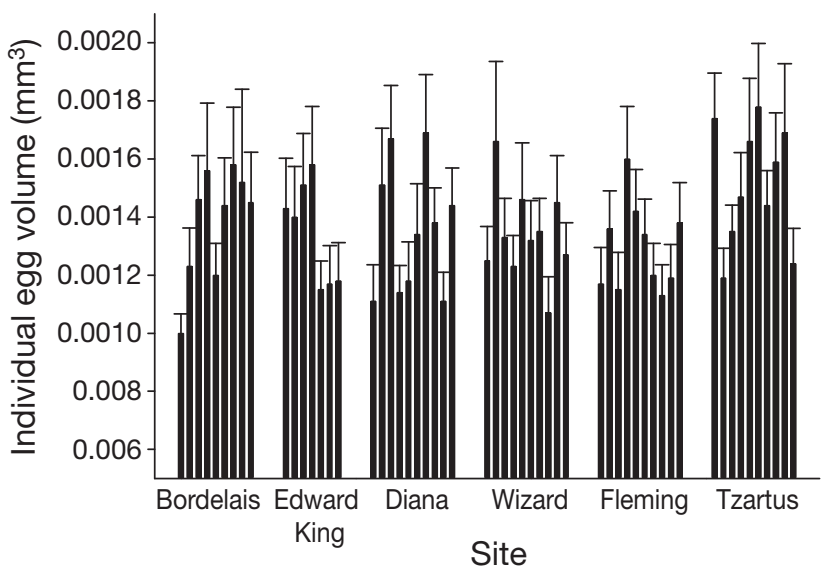

Fig. 3. Strongylocentrotus franciscanus. Egg volume from individual females at 6 sites along a horizontal gradient in Barkley Sound. Each bar represents the mean of 200 eggs measured from 1 female; error bars are $+1 \mathrm{SE}$
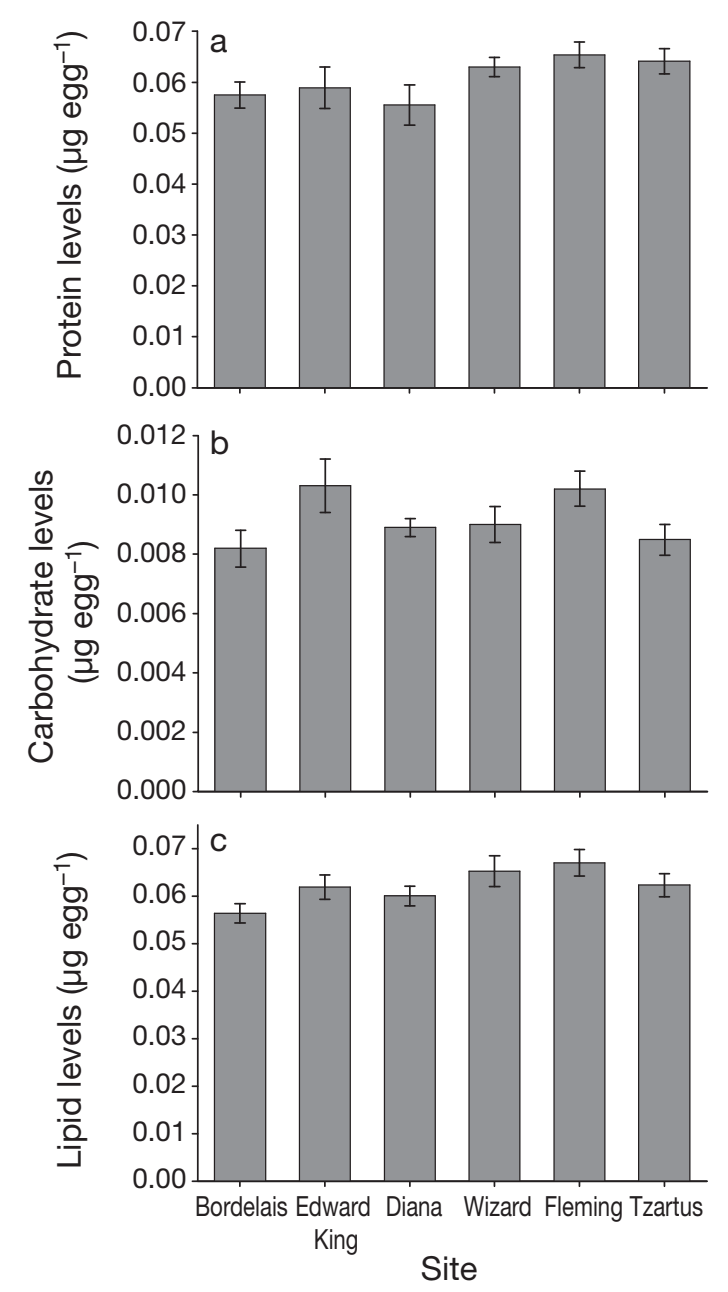

Fig. 4. Strongylocentrotus franciscanus. Egg biochemistry at 6 sites along a horizontal gradient in Barkley Sound for (a) protein levels, (b) carbohydrate levels, and (c) total lipid levels. Bars represent the mean from 10 individual females, with the exception of 7 at Edward King. Error bars are $\pm 1 \mathrm{SE}$

vary across locations. There was no significant correlation between egg volume and levels of protein $(\mathrm{r}=$ $0.198, p=0.14)$, carbohydrate $(r=0.03, p=0.87)$, or lipid $(\mathrm{r}=0.04, \mathrm{p}=0.77)$. Although mean percent carbon, a proxy for lipid level, was not significantly different between sites (ANOVA, $F_{5,48}=1.04, \mathrm{p}=0.41$ ), mean levels did increase as much as $4.4 \%$ as distance from the open coast increased (Table 2).

The $\delta^{13} \mathrm{C}$ values in Strongylocentrotus franciscanus eggs and tube feet showed variation along a horizontal gradient in Barkley Sound (ANOVA, $F_{5,48}=23.17, \mathrm{p}=$ 0.000). Lower carbon isotope ratios (more negative) indicate a terrestrial origin and higher values (more positive) a marine origin. At both ends of the gradient (i.e. Bordelais and Tzartus), $\delta^{13} \mathrm{C}$ values were more negative compared to all other locations (Tukey HSD, $\mathrm{df}=48, \mathrm{p}<0.05$; Fig. 5a). Across all locations $\delta^{13} \mathrm{C}$ 
Table 2. Strongylocentrotus franciscanus. Mean percent carbon $(\mathrm{C})$ and percent nitrogen $(\mathrm{N})$ in egg and tube foot tissue at 6 sites in Barkley Sound, British Columbia. Values in parentheses represent $1 \mathrm{SE}$

\begin{tabular}{|lcccc|}
\hline Site & Egg \% C & Tube foot \% C & Egg \% N & Tube foot \% N \\
\hline Bordelais & $43.67(2.37)$ & $37.53(2.03)$ & $8.47(0.45)$ & $8.89(0.53)$ \\
Edward King & $44.43(2.75)$ & $31.26(1.95)$ & $8.69(0.50)$ & $6.97(0.50)$ \\
Diana & $44.78(2.28)$ & $36.08(1.43)$ & $8.74(0.47)$ & $8.68(0.56)$ \\
Wizard & $45.99(1.95)$ & $37.65(1.82)$ & $9.42(0.50)$ & $9.16(0.67)$ \\
Fleming & $46.82(2.53)$ & $36.94(1.58)$ & $9.37(0.54)$ & $8.23(0.35)$ \\
Tzartus & $48.04(2.86)$ & $34.94(0.74)$ & $9.29(0.57)$ & $8.10(0.21)$ \\
\hline
\end{tabular}

values were significantly more negative in eggs compared to tube feet $\left(\mathrm{ANOVA}, F_{1,48}=410.94, \mathrm{p}=0.000\right.$; Fig. 5a) with combined mean values (SE) for eggs and tube feet of $-17.03(0.19)$ and $-14.03(0.17)$, respectively.

The $\delta^{15} \mathrm{~N}$ values for eggs and tube feet also varied spatially (ANOVA, $F_{5,48}=5.97, \mathrm{p}=0.000$ ) with the highest values observed at Wizard and Fleming for eggs and Diana and Wizard for tube feet (Fig. 5b). The
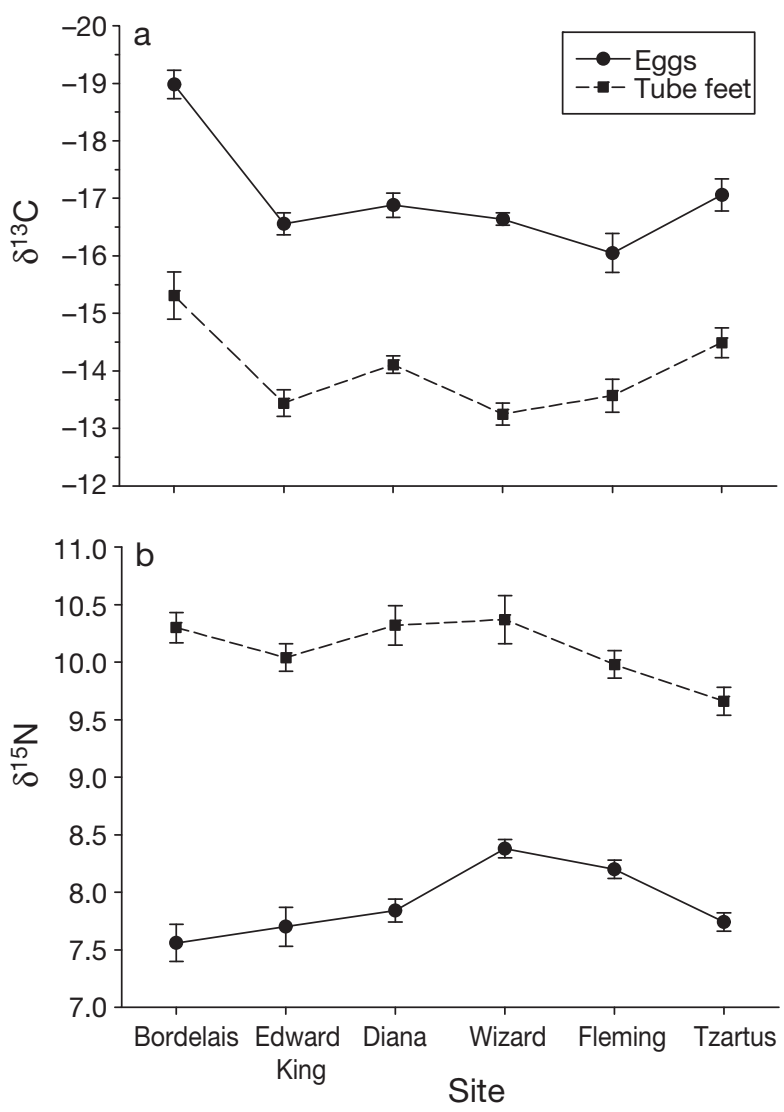

Fig. 5. Strongylocentrotus franciscanus. Stable (a) $\delta^{13} \mathrm{C}$ and (b) $\delta^{15} \mathrm{~N}$ isotope values for egg and tube feet tissue collected along a horizontal gradient in Barkley Sound, British Columbia. Each data point represents the mean of 3 individuals; error bars are $\pm 1 \mathrm{SE}$ $\delta^{15} \mathrm{~N}$ values were ca. 2 to $3 \%$ o lower in egg samples compared to tube feet across all locations (ANOVA, $F_{1,48}=$ 806.15, $p=0.000$; Fig. 5b).

Eggs had a higher percent carbon compared to tube feet (ANOVA, $F_{1,48}=$ $66.43, \mathrm{p}=0.000)$, but percent nitrogen was similar between the 2 tissue types $\left(\right.$ ANOVA, $F_{1,48}=3.46, \mathrm{p}=0.069$; Table 2).

\section{DISCUSSION}

We hypothesized that reproductive traits in Strongylocentrotus franciscanus would vary along a spatial gradient where environmental conditions in Barkley Sound were influenced by wave exposure and terrestrial runoff. Over the range of conditions that occurs in Barkley Sound, we found that a decrease in wave exposure concomitant with an increase in terrestrial influence resulted in only site-specific variation in fecundity. We did not find change in egg volume or egg biochemistry between sites.

Life-history models suggest that a tradeoff between number and size of eggs produced should result in an optimal egg size (Smith \& Fretwell 1974, Stearns 1992). Larger eggs have been shown to confer higher larval and post-metamorphic fitness (Emlet \& HoeghGuldberg 1997, Bertram \& Strathmann 1998) or increase the probability of fertilization success (Levitan 1996, but see Styan et al. 2005). However, intrapopulation variation in egg size is common in many species (Turner \& Lawrence 1979, McEdward \& Carson 1987, Jones et al. 1996). We show this to be the case for Strongylocentrotus franciscanus in the present study, where within a population that experiences similar environmental conditions, significant variation in egg volume occurred between mothers.

In terms of egg size between populations arrayed along a gradient of wave energy, we found no effect. Site-specific changes in marine invertebrate egg size have been shown to occur along depth gradients (Bertram \& Strathmann 1998), wave exposure gradients (George et al. 1990; however, see McEdward \& Carson 1987), and among other environmental gradients (Jones et al. 1996). Food limitation, temperature, and salinity, which all could vary along our sampled transect, have been proposed for between-population differences in egg size (Emlet et al. 1987, Garrido \& Barber 2001). Our data suggests that strong environmental gradients do not necessarily result in sitespecific changes in size and composition of eggs.

Stronglyocentrotus franciscanus, in a low wave energy environment and in close proximity to an estu- 
arine environment, released the greatest number of eggs. Food limitation may decrease the number of offspring produced (Keats et al. 1984, Meidel \& Scheibling 1999). We did not measure the quality and quantity of available food at the study sites and can only infer from nitrogen isotope ratios that urchins were obtaining food from different sources. This is not surprising because $S$. franciscanus is an opportunistic herbivore known to forage on attached and adrift macroalgae, encrusting organisms, and diatoms (reviewed in Lawrence 1975). S. franciscanus has also been observed to opportunistically scavenge on salp tests (Duggins 1981). One explanation for an increase in fecundity at the site furthest from the open coast could be an increase in the quality or quantity of available food. Exposure to increased levels of wave energy can either increase energy expenditures by forcing urchins to migrate to refugia or decrease available feeding time while the urchin remains strongly attached to the substrate (Kawamata 1998, Siddon \& Witman 2003). Additionally, urchins in high wave energy sites often experience spine damage (Ebert 1968), which has been to shown to allocate resources to spine, test, and lantern calcification (Edwards \& Ebert 1991). An alternative explanation is that increased energy expenditures at wave-exposed sites resulted in reduced urchin fecundity.

Environmental conditions have been shown to affect egg biochemistry in marine invertebrates (Bayne et al. 1978, George et al. 1990). In the present study, lipid, carbohydrate, and protein levels did not vary significantly between sites. However, a trend for an increase in percent carbon in eggs with distance from the open coast did occur, suggesting that sites with less wave exposure and/or an increased terrestrial input had eggs with higher lipid levels. Lipid levels have been shown to correlate with carbon content (Petersen \& Anger 1997). Examining percent carbon may be a more precise measure of lipid levels than the charring method of Bligh \& Dyer (1959) used in the present study. Relatively high levels of phospholipids may have masked site-specific differences in lipid levels analyzed with the charring method.

We hypothesized that terrestrial carbon may influence egg gametogenesis and that this relationship is expressed along a gradient of decreasing distance from estuarine sources. However, and contrary to our hypothesis, we found little variation in carbon isotope signatures and, paradoxically, the site farthest from estuarine sources had the strongest terrestrial signal. Our best explanation for this is that high intensity waves 'wash' locally produced carbon from Bordelais Island into the adjacent subtidal zone in a concentration greater than that transported long distance from distant upland and estuarine sources. In nearby Clay- oquot Sound, Mulkins et al. (2002) mapped the carbon isotopic signature of mysids in a bay and found the strongest terrestrial signal at the most marinedominated site in the study. They attributed the lack of an obvious spatial pattern to hydrodynamic conditions 'diluting' terrestrial organic matter in complex ways (Mulkins et al. 2002).

Although there were statistically different $\delta^{15} \mathrm{~N}$ values across sites, those differences were always less than $1 \%$. A change of ca. 3 to $4 \%$ in $\delta^{15} \mathrm{~N}$ indicates a shift in trophic level (DeNiro \& Epstein 1981, McCutchan et al. 2003). Therefore, small site-specific differences of $\delta^{15} \mathrm{~N}$ in the present study do not reflect any obvious trophic level shift in feeding but rather reflect site-specific feeding opportunities.

Of interest are the tissue-specific differences in carbon and nitrogen isotopic signatures. A ca. $3 \%$ decrease in $\delta^{13} \mathrm{C}$ was observed in urchin eggs compared to tube feet. Urchin eggs are high in lipid compared to the muscle tissue of tube feet (Van Dover et al. 1992). Since lipids tend to be depleted in ${ }^{13} \mathrm{C}$ (DeNiro \& Epstein 1978, Focken \& Becker 1998), a more negative $\delta^{13} \mathrm{C}$ value in egg samples is explained by relatively high lipid levels. McCutchan et al. (2003) found a change of ca. $1 \%$ in $\delta^{13} \mathrm{C}$ values when lipid-free muscle tissue was compared to muscle tissue containing lipids. Our differences were greater than $1 \%$ between tissue types; high levels of lipids in egg samples might not account for the total difference. Therefore, we suggest that a shift in $\delta^{13} \mathrm{C}$ value between eggs and tube feet was in part an artifact of tissue type, but also may be due to the uptake of DOM by tube feet (discussed below).

Two potential scenarios may explain why $\delta^{15} \mathrm{~N}$ levels were ca. 2 to $3 \%$ higher in tube feet compared to eggs. First, eggs and tube feet may be formed at different times when red urchins are feeding on different food sources at different times of the year, suggesting that a temporal shift in trophic feeding level may have occurred. As pointed out previously, Strongylocentrotus franciscanus are opportunistic with a variable diet (Duggins 1981). We know that $\delta^{15} \mathrm{~N}$ derived from food can vary over temporal scales and be integrated over time (Hesslein et al. 1992, Jennings et al. 1997). S. franciscanus oocyte growth occurs during late summer and fall with maximal development during October in southern British Columbia (Bernard 1977, Pearse 1981), and the signatures in tube feet may represent integration over a longer time period than oocyte formation. Second, the difference in $\delta^{15} \mathrm{~N}$ values between tissue types might instead be due to uptake of DOM by external tissues such as tube feet. Echinoderms take up DOM in external epidermal tissue, including tube feet, without taking up DOM into internal tissues, such as gonads (Fontaine \& Chia 1968, Ferguson 1982). 
To conclude, our findings suggest that despite the strong gradients of land-based runoff and wave exposure in Barkley Sound, size, and composition of eggs in urchins are surprisingly consistent between sites. This suggests that urchins have significant phenotypic plasticity with respect to resource allocation and fitnessrelated proxies. Except for fecundity at the extreme end of the gradient, urchin egg size and composition are not impacted by increased runoff in the near-shore coastal zone. This finding is intriguing insofar as possible consequences of climate change and increased freshwater runoff of the near-shore coastal zone. We posit that in environments such as Barkley Sound, urchins will be largely unaffected by an enhanced winter estuarine pump.

Acknowledgements. We thank L. Burgoyne, T. Douthwright, C. Fox, and J. Mortimer for help in the field and A. Moran for help with laboratory procedures. We also thank the staff at the Bamfield Marine Sciences Centre for logistical support. Earlier drafts of this manuscript were improved from comments by S. Gilman, D. Pace, and R. Strathmann. The Helen Riaboff Whiteley Center, University of Washington Friday Harbor Laboratories, provided support to complete this manuscript. Funding was provided by a Pacific Institutes of Marine Sciences Fellowship to M.S.B. and an NSERC grant to D.E.J.

\section{LITERATURE CITED}

Ballantine WJ (1961) A biologically-defined exposure scale for comparative description of rocky shores. Field Stud 1:1-19

Bayne BL, Holland DL, Moore MN, Lowe DM, Widdows J (1978) Further studies on the effects of stress in the adult on the eggs of Mytilus edulis. J Mar Biol Assoc UK 58:825-841

Berger MS, Darrah AJ, Emlet RB (2006) Spatial and temporal variability of early post-settlement survivorship and growth in the barnacle Balanus glandula along an estuarine gradient. J Exp Mar Biol Ecol 336:74-87

Bernard DF (1977) Fishery and reproductive cycle of the red sea urchin, Strongylocentrotus franciscanus, in British Columbia. J Fish Res Board Can 34:604-610

Bertram DF, Strathmann RR (1998) Effects of maternal and larval nutrition on growth and form of planktotrophic larvae. Ecology 79:315-327

Bligh EG, Dyer WF (1959) A rapid method of total lipid extraction and purification. Can J Biochem Physiol 37:911-917

Bradford MM (1976) A rapid and sensitive method for the quantification of microgram quantities of protein utilizing the principle of protein-dye binding. Anal Biochem 72: 248-254

Bromirski PD, Flick RE, Cayan DR (2003) Storminess variability along the California coast: 1858-2000. J Clim 16: 982-993

Cushing DH (1995) Population production and regulation in the sea: a fisheries perspective. Cambridge University Press, Cambridge

> Darnaude AM (2005) Fish ecology and terrestrial carbon use in coastal areas: implications for marine fish production. J Anim Ecol 74:864-876

> Darnaude AM, Salen-Picard C, Polunin NVC, HarmelinVivien ML (2004) Trophodynamic linkage between river runoff and coastal fishery yield elucidated by stable isotope data in the Gulf of Lions (NW Mediterranean). Oecologia 138:325-332

Day JW Jr, Hall CAS, Kemp WM, Yanez-Arancibia A (1989) Estuarine ecology. John Wiley and Sons, New York

DeNiro MJ, Epstein S (1978) Influence of diet on the distribution of carbon isotopes in animals. Geochim Cosmochim Acta 42:495-506

DeNiro MJ, Epstein S (1981) Influence of diet on the distribution of nitrogen isotopes in animals. Geochim Cosmochim Acta 45:341-351

> Diez I, Santolaria A, Gorostiaga JM (2003) The relationship of environmental factors to the structure and distribution of subtidal seaweed vegetation of the western Basque coast (N Spain). Estuar Coast Shelf Sci 56:1041-1054

Duggins DO (1981) Sea urchins and kelp: the effects of shortterm changes in urchin diet. Limnol Oceanogr 1981: 391-394

Ebert TA (1968) Growth rates of the sea urchin Strongylocentrotus purpuratus related to food availability and spine abrasion. Ecology 49:1075-1091

Edwards PB, Ebert TA (1991) Plastic responses to limited food availability and spine damage in the sea urchin Strongylocentrotus purpuratus (Stimpson). J Exp Mar Biol Ecol 145: $205-220$

Emlet RB, Hoegh-Guldberg O (1997) Effects of egg size on postlarval performance: experimental evidence from a sea urchin. Evolution 51:141-152

Emlet RB, McEdward LR, Strathmann RR (1987) Echinoderm larval ecology viewed from the egg. In: Jangoux $M$, Lawrence JM (eds) Echinoderm studies, Vol 2. Balkema, Rotterdam, p 55-136

Ferguson JC (1982) A comparative study of the net metabolic benefits derived from the uptake and release of free amino acids by marine invertebrates. Biol Bull 162:1-17

Focken U, Becker K (1998) Metabolic fractionation of stable carbon isotopes: implications of different proximate compositions for studies of the aquatic food webs using $\delta^{13} \mathrm{C}$ data. Oecologia 115:337-343

Fontaine AR, Chia FS (1968) Echinoderms: an autoradiographic study of assimilation of dissolved organic molecules. Science 161:1153-1155

Gannes LZ, O'Brian DM, Martinez del Rio C (1997) Stable isotopes in animal ecology: assumptions, caveats, and a call for more laboratory experiments. Ecology 78:1271-1276

Garrido CL, Barber BJ (2001) Effects of temperature and food ration on gonad growth and oogenesis of the green sea urchin, Strongylocentrotus droebachiensis. Mar Biol 138: $447-456$

> George SB, Cellario C, Fenaux L (1990) Population differences in egg quality of Arbacia lixula (Echinodermata: Echinoidea): proximate composition of eggs and larval development. J Exp Mar Biol Ecol 141:107-118

Graham NE, Diaz HF (2001) Evidence for intensification of North Pacific winter cyclones since 1948. Bull Am Meteorol Soc 82:1869-1893

Harrold C, Watanabe J, Lisin S (1988) Spatial variation in the structure of kelp forest communities along a wave exposure gradient. Mar Ecol 9(2):131-156

Hesslein RH, Capel MD, Fox DE, Hallard KA (1992) Stable isotopes of sulfur, carbon, and nitrogen as indicators of trophic level and fish migration in the lower Mackenzie River Basin, Canada. Can J Fish Aquat Sci 48:2258-2265

Holland DL (1978) Lipid reserves and energy metabolism in the larvae of benthic marine invertebrates. In: Malins DC, Sargent JR (eds) Biochemical and biophysical perspectives in marine biology. Academic Press, London, p 85-123 
Holland DL, Gabbott PA (1971) A micro-analytical scheme for the determination of protein, carbohydrate, lipid and RNA levels in marine invertebrate larvae. J Mar Biol Assoc UK 51:659-668

- Jennings S, Renones O, Morales-Nin B, Polunin NVC, Moranta J, Coll J (1997) Spatial variation in the ${ }^{15} \mathrm{~N}$ and ${ }^{13} \mathrm{C}$ stable isotope composition of plants, invertebrates and fishes on Mediterranean reefs: implications for the study of trophic pathways. Mar Ecol Prog Ser 146:109-116

Jones HL, Todd CD, Lambert WJ (1996) Intraspecific variation in embryonic and larval traits of the dorid nudibranch mollusc Adalaria proxima (Alder and Hancock) around the northern coasts of the British Isles. J Exp Mar Biol Ecol 202:29-47

Kawamata S (1998) Effect of wave-induced oscillatory flow on grazing by a subtidal sea urchin Strongylocentrotus nudus (A. Agassiz). J Exp Mar Biol Ecol 224:31-48

Keats DW, Steele DH, South GR (1984) Depth-dependent reproductive output of the green sea urchin, Strongylocentrotus droebachiensis (O. F. Muller), in relation to the nature and availability of food. J Exp Mar Biol Ecol 80: $77-91$

Lares MT, Pomory CM (1998) Use of body components during starvation in Lytechinus variegatus (Lamarck) (Echinodermata: Echinoidea). J Exp Mar Biol Ecol 225:99-106

Lawrence JM (1975) On the relationships between marine plants and sea urchins. Oceanogr Mar Biol Annu Rev 13: 213-286

> Levitan DR (1989) Density-dependent size regulation in Diadema antillarum: effects on fecundity and survivorship. Ecology 70:1414-1424

Levitan DR (1996) Predicting optimal and unique egg sizes in free-spawning marine invertebrates. Am Nat 148:174-188

Lloret J, Lleonart J, Solé I, Fromentin JM (2001) Fluctuations of landings and environmental conditions in the northwestern Mediterranean Sea. Fish Oceanogr 10:33-50

Longhurst A (1998) Ecological geography of the sea. Academic Press, New York

McCutchan JH, William ML, Kendall C, McGrath CC (2003) Variation in trophic shift for stable isotope ratios of carbon, nitrogen, and sulfur. Oikos 102:378-390

McEdward LR, Carson SF (1987) Variation in egg organic content and its relationship with egg size in the starfish Solaster stimpsoni. Mar Ecol Prog Ser 37:159-169

Meidel SK, Scheibling RE (1999) Effects of food type and ration on reproductive maturation and growth of the sea urchin Strongylocentrotus droebachiensis. Mar Biol 134: 155-166

Mulkins LM, Jelinski DE, Karagatzides JD, Carr A (2002) Car-

Initial editorial responsibility: Howard Browman, Storebø, Norway; Final editorial responsibility: Matthias Seaman, Oldendorf/Luhe, Germany bon isotope composition of mysids at a terrestrial-marine ecotone, Clayoquot Sound, British Columbia, Canada. Estuar Coast Shelf Sci 54:669-675

Pearse JS (1981) Synchronization of gametogenesis in the sea urchin Strongylocentrotus purpuratus and S. franciscanus. In: Clark WH Jr, Adams TS (eds) Advances in invertebrate reproduction. Elsevier/North-Holland, New York, p 53-68

$>$ Petersen S, Anger K (1997) Chemical and physiological changes during the embryonic development of the spider crab, Hyas araneus L. (Decapoda; Majidae). Comp Biochem Physiol 117:299-306

Peterson BJ, Fry B (1987) Stable isotopes in ecosystem studies. Annu Rev Ecol Syst 18:293-320

Reimchen TE (1979) Substratum heterogeneity, crypsis, and colour polymorphism in an intertidal snail (Littorina mariae). Can J Zool 57:1070-1085

Romanuk TN, Levings CG (2006) Relationships between fish and supralittoral vegetation in near-shore marine habitats. Aquat Conserv: Mar Freshw Ecosyst 16:115-132

Salomon AK, Ruesink JL, DeWreede RE (2006) Population viability, ecological processes and biodiversity: valuing sites for reserve selection. Biol Conserv 128:79-92

Siddon CE, Witman JD (2003) Influence of chronic, low-level hydrodynamic forces on subtidal community structure. Mar Ecol Prog Ser 261:99-110

Smith CC, Fretwell SD (1974) The optimal balance between size and number of offspring. Am Nat 108:499-506

Stearns SC (1992) The evolution of life histories. Oxford University Press, Oxford

> Styan CA, Bryrne M, Franke E (2005) Evolution of egg size and fertilisation efficiency in sea stars: Large eggs are not fertilised more readily than small eggs in the genus Patiriella (Echinodermata: Asteroidea). Mar Biol 147:235-242

Taylor FJR, Haigh R (1996) Spatial and temporal distributions of microplankton during the summers of 1992-1993 in Barkley Sound, British Columbia, with emphasis on harmful species. Can J Fish Aquat Sci 53:2310-2322

Tully JP (1949) Oceanography and prediction of pulp mill pollution in Alberni Inlet. Bull Fish Res Board Can 83:1-169

Turner RL, Lawrence JM (1979) Volume and composition of echinoderm eggs: implications for the use of egg size in life-history models. In: Stancyk SE (ed) Reproductive ecology of marine invertebrates, Vol 9. University of South Carolina Press, Columbia, SC, p 25-40

Van Dover CE, Grassle JF, Fry B, Garritt RH, Starczak VR (1992) Stable isotope evidence for entry of sewagederived organic material into a deep-sea food web. Nature 360:153-155

Submitted: September 3, 2007; Accepted: March 25, 2008 Proofs received from author(s): July 10, 2008 